\title{
PENILAIAN INDEKS KUALITAS LINGKUNGAN UNTUK MENENTUKAN WILAYAH KONSERVASI IKAN BELIDA (Chitala lopis) DI SUNGAI KAMPAR, RIAU
}

\section{WATER QUALITY EVALUATION BY INDEX FOR THE ASSESMENT OF ITS SUITABILITY FOR APPROPRIATE A SPECIAL CONSERVATION AREA OF GIANT FEATHERBACK (Chitala lopis) IN KAMPAR RIVER, RIAU}

\author{
Arif Wibowo dan Subagja \\ Peneliti pada Balai Penelitian Perikanan Perairan Umum-Palembang \\ Teregistrasi I tanggal: 08 September 2012; Diterima setelah perbaikan tanggal: 07 April 2014; \\ Disetujui terbit tanggal: 09 April 2014 \\ E-mail:wibarf@yahoo.com
}

\begin{abstract}
ABSTRAK
Populasi ikan belida yang menurun sehingga memerlukan strategi pengelolaan yang tepat melalui penetapan wilayah konservasi. Pemilihan wilayah konservasi dapat dilakukan melalui penilaian kondisi habitat dikaitkan dengan faktor kondisi ikan belida. Penelitian ini bertujuan mengetahui indeks kualitas perairan kondisi habitat dan keterkaitannya dengan faktor kondisi ikan belida di Sungai Kampar. Penelitian dilakukan dari bulan Mei 2009 sampai dengan November 2010 dengan interval pengambilan sampel setiap 3 bulan sekali. Pengamatan dilakukan pada lima stasiun di Sungai Kampar Propinsi, Riau. Parameter lingkungan yang diamati adalah suhu, kedalaman, kecepatan arus, $\mathrm{pH}$, oksigen terlarut, turbiditas, alkalinitas, amoniak dan vegetasi tepian. Data sekunder yang dikoleksi adalah curah hujan dan debit air sedangkan data sekunder yang terkait ikan berupa nilai koefisien pertumbuhan, faktor kondisi, nilai b, luas relung dan indeks kepenuhan lambung. Penilaian kondisi perairan dilakukan dengan metode skoring dengan pembobotan. Keterkaitan antara kondisi perairan dengan faktor kondisi ikan dilakukan dengan menggunakan analisa komponen utama dan analisa kluster. Hasil pengamatan kualitas lingkungan perairan menunjukkan Stasiun Kuala Tolam memiliki nilai indeks kualitas lingkungan perairan yang terbaik sedangkan Stasiun Teso dan Rantau Baru yang paling buruk. Nilai K memiliki keterkaitan yang paling kuat dengan indeks kualitas lingkungan. Berdasarkan penilaian kondisi habitat yang paling baik, Stasiun Kuala Tolam di Sungai Kampar Propinsi. Riau merupakan kandidat yang tepat untuk direkomendasikan sebagai wilayah konservasi ikan belida.
\end{abstract}

KATA KUNCI: Indeks kualitas lingkungan, ikan belida, Sungai Kampar

\begin{abstract}
Declining giant featherback populations require appropriate management strategiy and zoning for conservation. The selection of conservation areas can be done through habitat assesment is linked to condition factor of giant featherback. This study aims are to determine the water quality index of habitat condition and its association with giant featherback in Kampar River. The study was conducted from May 2009 to November 2010 with a sampling interval of once every 3 months. Observations was conducted at five stations in Kampar River, Riau Province. The environmental parameters such as temperature, depth, flow velocity, $\mathrm{pH}, \mathrm{O} 2$ turbidity, alkalinity, ammonia and riparian vegetation were measured. Rainfall and water discharge were collected as secondary data of environmental parameter. While fish-related coefficient growth, condition factor, the b value, broad niches and stomach fullness index were conjoined as secondary data from fish perspective. Assessment of water quality were conducted using the weighting scoring method. The relationship analysis of between water quaility and condition factor was performed using principal component analysis and cluster analysis. The results reveal that Kuala Tolam has the highest water quality index, opposite to Teso and Rantau Baru sampling station, where as these two station display the worst. Based on the assessment, Kuala Tolam stasion is the most suitable candidate designated as conservation area. It was summary that water quality index related to giant featherback's growth ( $b$ value and $K$ value), with the strongest relationship with $K$ value.
\end{abstract}

KEYWORDS: Water quality index, giant featherback, Kampar River 


\section{PENDAHULUAN}

Populasi ikan belida yang menurun karena eksploitasi yang berlebihan dan degradasi lingkungan (Pollnac \& Malvestuto, 1991) memerlukan strategi pengelolaan yang tepat dan penetapan wilayah konservasi menjadi salah satu realisasi yang dinilai tepat dalam upaya pengelolaan ikan belida. Hal pertama yang harus dilakukan adalah pemilihan wilayah konservasi dengan cara melakukan penilaian wilayah atau habitat. Habitat adalah wilayah ekologi atau lingkungan yang dihuni oleh spesies tertentu dari hewan, tumbuhan, atau jenis lain dari organisme (Abercrombie et al., 1966). Habitat ikan adalah badan air dan substrat yang diperlukan untuk pemijahan ikan, berkembang biak, makan, dan tempat mereka dapat bertumbuh menjadi dewasa. Badan air (air tawar, muara dan sistem air asin) yang digunakan sebagai habitat ikan memiliki sifat fisik, kimia, dan komponen biologis dan juga mencakup lingkungan perairan yang selalu digunakan ikan terkait dengan sejarah hidupnya (Rosenberg et al., 2000).

Penilaian habitat sering digunakan sebagai dasar pembuatan kebijakan dalam memilih wilayah konservasi (Rossi \& Kuitenen, 1996). Penilaian tentang habitat ikan penting untuk tujuan konservasi dan secara umum telah dilakukan (Goldsmith, 1983) dengan tujuan untuk menghindari kepunahan spesies atau komunitas (Kirkpatrick, 1983). Kegiatan pemilihan habitat konservasi melibatkan koleksi data yang relevan melalui pembobotan berbagai parameter konservasi dan selanjutnya mengaplikasikan formula untuk menjelaskan rangking dari yang terendah hingga yang paling bernilai (Kirkpatrick, 1983).

Kondisi habitat dapat diklasifikasi berdasarkan rangking habitat. Rangking habitat ikan sebelum pelaksanaan upaya konservasi merupakan pendekatan yang realistik dan berguna dalam membandingkan nilai dari komponen yang berbeda dari lingkungan alam (Rossi \& Kuitenen, 1996). Margules \& Usher (1981), menyatakan definisi arbitari dan penilaian tidak membawa kepada kuantifikasi murni, namun dengan mencoba mengkuantifikasi kita dapat membandingkan secara tepat dari sesuatu yang dinilai. Penilaian habitat ikan belida dapat mengkaitkan faktor kualitas air dan faktor kondisi ikan dan memberikan kontribusi yang penting dalam membuat kebijakan berkaitan dengan pengelolaan sumberdaya ikan belida.

Kegiatan penilaian habitat diharapkan bersifat spesifik lokasi dan komprehensif, baik kajian tentang habitat maupun keterkaitannya dengan ikan belida. Penelitian Adjie \& Utomo (1994); Adjie et al. (1999) \& Wibowo et al. (2009) memberikan baseline data karakteristik kondisi perairan untuk konservasi ikan belida di berbagai tipe perairan, namun bersifat umum dan kurang kuat untuk acuan pemilihan wilayah konservasi ikan belida spesifik di Sungai Kampar. Penelitian ini bertujuan menentukan wilayah konservasi ikan belida yang terbaik di Sungai Kamar, Prov. Riau melalui pendekatan penilaian habitat dikaitkan dengan faktor kondisi ikan.

\section{BAHANDANMETODE}

\section{Waktu dan Tempat Penelitian}

Penelitian dilakukan dari bulan Mei 2009 sampai dengan November 2010 dengan interval pengambilan sampel setiap 3 bulan sekali. Pengamatan kualitas perairan di lakukan pada lima stasiun di Sungai Kampar Prov Riau. (Gambar 1, Tabel 1). Parameter suhu, kedalaman, kecepatan arus, $\mathrm{pH}$ dan $\mathrm{O}_{2}$ dianalisis di tempat (in-situ) di Sungai Kampar. Pengukuran turbiditas, alkalinitas dan amoniak, dilakukan di Laboratorium Kimia Lingkungan, Balai Penelitian Perikanan Perairan Umum (BP3U), Palembang.

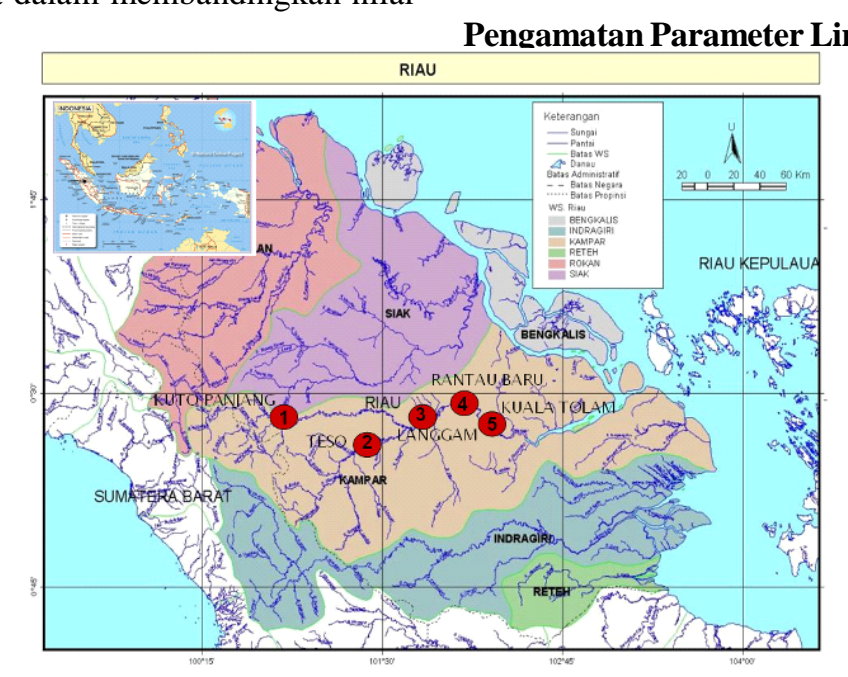

Gambar 1. Lokasi penelitian kualitas lingkungan di Sungai Kampar

Figure 1. Sampling stations for water quality analysis in Kampar River 
Tabel 1. Keterangan lokasi penelitian penelitian di Sungai Kampar

Table 1. Description of sampling stations in Kampar River

\begin{tabular}{|c|c|c|c|}
\hline $\begin{array}{l}\text { Informasi } \\
\text { Lokasi (No) }\end{array}$ & Nama Stasiun & Posisi Geografis & Diskripsi Kondisi Fisik \\
\hline 1 & $\begin{array}{c}\text { Waduk } \\
\text { Kutopanjang }\end{array}$ & $\begin{array}{l}00^{0} 19 ' 5,39 ” \mathrm{LU} \\
100^{\circ} 44^{\prime} 3,79 ” \mathrm{BT}\end{array}$ & $\begin{array}{l}\text { tipe perairan waduk, daerah sekitar Desa Batu } \\
\text { Bersurat }\end{array}$ \\
\hline 2 & Teso & $\begin{array}{l}00^{0} 03 \text { '2,34” LU, } \\
101^{0} 23{ }^{\prime} 2,71^{\prime \prime} \mathrm{BT}\end{array}$ & bagian hulu Sungai Kampar, Sungai Kampar kiri \\
\hline 3 & Langgam & $\begin{array}{l}00^{0} 15^{\prime} 4,69 " \mathrm{LU} \\
101^{0} 422^{\prime} 4,55^{\prime} \mathrm{BT}\end{array}$ & $\begin{array}{l}\text { bagian tengah Sungai Kampar, memiliki berbagai } \\
\text { tipe perairan, seperti: sungai utama, anak sungai dan } \\
\text { danau rawa. }\end{array}$ \\
\hline 4 & Rantau Baru & $\begin{array}{l}00^{0} 17^{\prime} 1,06 " \mathrm{LU} \\
101^{0} 48^{\prime} 1,22 " \mathrm{BT}\end{array}$ & $\begin{array}{l}\text { zona tengah mendekati hilir, dipengaruhi pasang } \\
\text { surut air laut }\end{array}$ \\
\hline 5 & Kuala Tolam & $\begin{array}{l}00^{0} 19^{\prime} 3,10^{\prime \prime} \mathrm{LU}, \\
102^{0} 11 ' 2,60 ” \mathrm{BT}\end{array}$ & $\begin{array}{l}\text { zona hilir Sungai Kampar, memiliki banyak vegetasi } \\
\text { tepian dengan perairan yang bersifat asam }\end{array}$ \\
\hline
\end{tabular}

Tabel 2. Parameter, metode pengukuran, bahan dan alat yang digunakan

Table 2. Parameters, measurement, method and material used

\begin{tabular}{|c|c|c|c|c|}
\hline No & $\begin{array}{c}\text { Parameter Yang } \\
\text { Diamati }\end{array}$ & Metode & Bahan & Alat \\
\hline I & Parameter Fisika & & & \\
\hline 1 & Suhu & Termografik & - & Termometer air raksa \\
\hline 2 & Kedalaman & Langsung & - & Depth sounder \\
\hline 3 & Kecepatan Arus & Langsung & - & Stopwatch dan tali penduga \\
\hline 4 & Turbiditas & Langsung & - & Turbidity meter \\
\hline II & Parameter Kimia & & & \\
\hline 1 & $\mathrm{pH}$ & Langsung & & $\mathrm{pH}$ indicator \\
\hline 2 & Oksigen terlarut & Langsung & - & DO Meter \\
\hline 3 & Kesadahan & Titrimetri & $\begin{array}{ll}- & \mathrm{H}_{2} \mathrm{SO}_{4} 0.02 \mathrm{~N} \\
- & (216 \mathrm{cc})\left(2.8 \mathrm{ml} \mathrm{H}_{2} \mathrm{SO}_{4} \text { p jadikan }\right. \\
& 100 \mathrm{ml}\left(\mathrm{H}_{2} \mathrm{SO}_{4} 0.1 \mathrm{~N}\right) \text { ambil } 200 \\
& \mathrm{H} 2 \mathrm{~S} 040.1 \mathrm{~N} \text { jadikan } 1000 \mathrm{ml} \\
& \left(\mathrm{H}_{2} \mathrm{SO}_{4} 0.02 \mathrm{~N}\right) \\
- & \text { Methyl Orange } \\
& \text { (576 tetes) }\end{array}$ & $\begin{array}{l}\text { - Erlemeyer } 250 \mathrm{ml} 1 \mathrm{bh} \\
\text { - Pipet ukur } 5 \mathrm{ml} 2 \mathrm{bh} \\
\text { - Pipet tetes } 2 \mathrm{bh} \\
\text { - Gelas ukur } 100 \mathrm{ml} 1 \mathrm{bh} \\
\text { - Botol Aquadest } 1 \mathrm{bh}\end{array}$ \\
\hline 4 & Amoniak & Titrimetri & - & - \\
\hline
\end{tabular}

Pengamatan parameter lingkungan dilakukan setiap 3 bulan sekali, Mei 2009, Juli 2009, November 2009, Februari 2010, April 2010, Mei 2010, Juli 2010 dan November 2010. Penentuan titik sampling untuk pengamatan parameter lingkungan disamakan dengan titik pengambilan sampel ikan belida. Pengambilan data kualitas air dilakukan sebanyak tiga kali ulangan dengan masing-masing jarak antar titik ulangan $\pm 10-500$ meter, pada masing-masing stasiun.

Pengamatan parameter fisika (suhu, kedalaman, kecepatan arus, turbiditas) dan kimia perairan $\left(\mathrm{pH}, \mathrm{O}_{2}\right.$, alkalinitas dan amoniak) berpedoman pada APHA, AWWA \& WPCF (1981), Bain \& Stevenson (1999) \& Effendi (2003) (Tabel 2). Sampel air diambil menggunakan botol sampel ukuran $500 \mathrm{ml}$ dengan 3 ulangan dan disimpan dalam kotak dingin yang suhunya selalu dijaga dingin. Analisa vegetasi riparian berupa persentase kerapatan vegetasi riparian berdasarkan peta citra dan foto yang dikuantifikasi, besaran yang diperoleh kemudian dilakukan skoring dan pembobotan (Jikalahari, 2009).

\section{Pengumpulan Data Sekunder Faktor Kondisi Ikan}

Data sekunder yang digunakan adalah data karakter faktor kondisi ikan, tempat dan waktu pengambilan contoh ikan memiliki kesamaan dengan pengamatan kualitas perairan, yaitu Waduk Kutopanjang, Teso, Langgam, Rantau Baru dan Kuala Tolam, sedangkan waktu pengambilan contoh ikannya Mei 2009, Juli 2009, November 2009, Februari 2010, April 2010, Mei 2010, Juni 2010 dan November 2010. Data tersebut berupa nilai K (koefisien pertumbuhan), faktor kondisi, nilai b (slope regresi antara logaritma yang diperoleh dari hubungan panjang dan berat), luas relung dan indeks kepenuhan lambung (ISC) (Wibowo, 2011). 


\section{Analisa Data Parameter Lingkungan}

\section{Penilaian kondisi kualitas perairan didasarkan kepada metode skoring dengan pembobotan}

Pengukuran sifat fisika, kimia dan biologi perairan di setiap lokasi pengamatan selanjutnya dibandingkan dengan standar kualitas air yang optimal yang mendukung pertumbuhan dan reproduksi ikan belida. Data parameter kualitas air yang optimum untuk pertumbuhan ikan belida mengacu kepada penelitian yang telah dilakukan oleh Adjie \& Utomo (1994), Adjie et al. (1999) yang secara spesifik mengungkapkan kualitas perairan tempat hidup ikan belida dan Affandi (komunikasi pribadi). Untuk mengeliminasi faktor variasi parameter yang diukur dihitung rerata parameter pengamatan setiap stasiun untuk kemudian dibuat indeks kualitas lingkungannya. Indeks kualitas lingkungan didefinisikan sebagai suatu tingkatan yang merefleksikan pengaruh campuran/gabungan pada parameter kualitas air yang berbeda (Ramakrishnalah et al., 2009).

Penentukan kondisi kualitas perairan disetiap lokasi pengamatan dilakukan menggunakan cara skoring indeks kualitas lingkungan (IKL). IKL merupakan perhitungan yang digunakan dalam upaya meringkas dan menyederhanakan data parameter lingkungan sehingga dapat memberikan informasi yang berguna dalam memahami kondisi lingkungan. Kondisi ideal kerapatan tumbuhan air dihitung dalam bentuk presentase penutupan vegetasi berdasarkan peta citra dan foto lapangan.

Tahapan analisis data untuk menentukan indeks kualitas lingkungan dengan cara skoring adalah sebagai berikut:

1. Untuk menghitung IKL dengan mengikuti beberapa tahap yaitu:

a. Seluruh parameter lingkungan (fisika, kimia dan biologi) yang sudah dirata-rata (dengan asumsi pengambilan sampel air pada musim yang sama di stasiun sampling), diberikan skoring atau skala penilaian kualitas dibandingkan dengan standar kualitas optimum terhadap ikan belida mengikuti pustaka acuan Adjie \& Utomo (1994), Adjie et al. (1999). Nilai kualitas perairan pengamatan yang sama nilainya dengan pustaka yang diacu diberi nilai maksimal, sedangkan nilai yang lebih besar dan kecil memiliki skor nilai yang lebih rendah dan besarannya sangat tergantung kisaran nilai selisihnya.

b. Tahap selanjutnya pemberian bobot nilai berdasarkan tingkatan kepentingan terhadap pertumbuhan dan reproduksi ikan belida. Bobot skor yaitu suhu (10\%), kecepatan arus (10\%), kedalaman (10\%), turbidity (10\%), oksigen (10\%),
$\mathrm{pH}(10 \%)$, alkalinitas (10\%), $\mathrm{NH}_{3} \mathrm{H}(10 \%)$ dan kerapatan vegetasi riparian (20\%), sehingga jumlah keseluruhan pembobotan adalah 100\% (Wibowo, 2011). Kerapatan vegetasi riparian memiliki bobot yang besar karena menyediakan habitat yang cocok untuk ikan belida, sepert; akar-akar vegetasi menyediakan tempat bagi perlindungan bagi induk dan anakan, akar dan batang yang rebah merupakan tempat menempelkan telur pada saat pemijahan dan di bawah vegetasi banyak ditemukan udang yang merupakan makanan favorit ikan belida (Wibowo, 2011).

2. Indeks kualitas lingkungan yang didapat, selanjutnya dilakukan skoring atau ditentukan nilai jangkauannya, dan nilai jangkauan ini dibagi menjadi 5 interval yang sama. Jumlah total skor (parameter yang telah skor dan dibobot) setiap stasiun pengambilan sampel dihitung ditentukan status kualitas perairannya dengan membandingkan terhadap kisaran nilai tertinggi dan terendah kualitas perairan dari 5 stasiun pengamatan.

\section{Analisa Kluster dan Komponen Utama}

Parameter kualitas perairan setiap stasiun selanjutnya dibandingkan dengan faktor kondisi ikan melalui analisa kluster dan analisa komponen utama ( $P C A)$. Pengelompokkan berdasarkan stasiun sampling, yaitu mengelompokkan parameter fisika (suhu, kedalaman, kecepatan arus, turbiditas), kimia perairan $\left(\mathrm{pH}, \mathrm{O}_{2}\right.$, alkalinitas dan amoniak), nilai $\mathrm{K}$ (koefisien pertumbuhan), faktor kondisi, nilai b (slope regresi antara logaritma yang diperoleh dari hubungan panjang dan berat), luas relung dan indek kepenuhan lambung (ISC). Pengelompokkan dilakukan pada masing-masing stasiun untuk selanjutnya melihat pola kecendrungan parameter yang menjadi karakteristik masing-masing stasiun.

Karakteristik masing-masing stasiun secara sederhana terlihat berdasarkan pendekatan PCA (Principal Component Análisis) (Legendre \& Legendre, 1998), sekaligus untuk mengetahui bagaimana pengaruh atau keterkaitan kondisi lingkungan perairan dengan pertumbuhan ikan. Parameter yang digunakan dalam analisis ini adalah faktor kondisi ikan, koefisien pertumbuhan $(\mathrm{K})$, nilai $\mathrm{b}$ (panjang berat), luas relung, parameter fisika (suhu air, kedalaman, kecepatan arus dan turbidity), parameter kimia (pH, DO, alkalinitas dan Amonia $\left(\mathrm{NH}_{3}-\mathrm{H}\right)$ ) dan parameter biologi (persentase tutupan vegetasi riparian).

Analisis kelompok dimaksudkan untuk mengelompokkan unit-unit statistik ke dalam kelompokkelompok yang homogen ini dari sejumlah variabel atau karakter yang di analisis. Pembentukan klaster didasarkan pada kuat tidaknya hubungan antar-objek yang merupakan 
konsep dari pengklasteran hierarki (Bengen, 2000). Dari hasil analisis akan didapat suatu matriks data yang nilainilainya menunjukkan seberapa dekat suatu karakter dan memiliki keterkaitan dengan karakter lainnya. Selain itu, hasil plot antar komponen utama (grafik score plot) digunakan untuk menentukan pengelompokkan secara sederhana (Bengen, 2000). Perhitungan dalam analisis komponen utama (PCA) dapat dibantu dengan mengunakan software XL-STAT versi 5.0 di dalam Microsoft excel 2003( Legendre \& Legendre, 1998).

\section{HASIL DAN BAHASAN}

\section{HASIL}

Proses dan dinamika hidrologi mempengaruhi komponen biotik dan abiotik dalam suatu ekosistem perairan yang nantinya akan mempengaruhi kondisi kualitas perairan. Hasil penilaian secara skoring pada masing-masing stasiun pengamatan kualitas air, menunjukkan Rantau Baru dan Stasiun Teso memiliki nilai IKL yang rendah (1) dan (2). Nilai IKL tertinggi adalah Stasiun Kuala Tolam (5) (Gambar 2). Stasiun Kuala Tolam memiliki kondisi parameter fisika, kimia dan biologi yang paling mendekati keadaan ideal bagi kehidupan ikan belida.

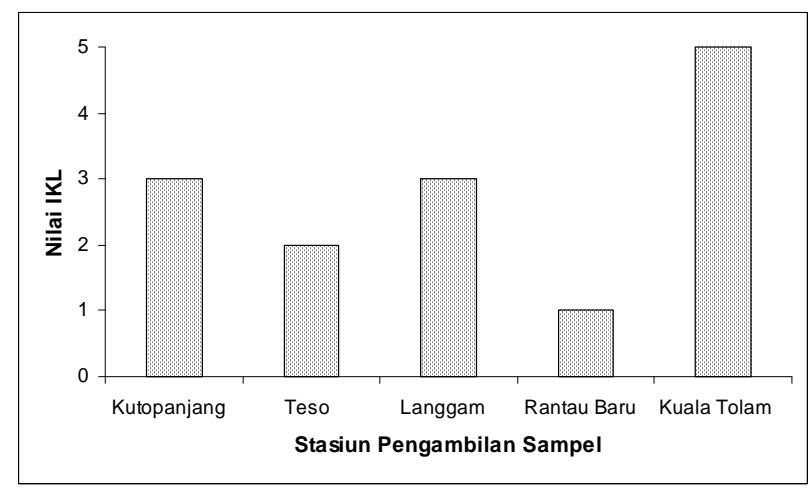

Gambar 2. Indeks kondisi kualitas perairan (IKL) di setiap stasiun pengamatan di Sungai Kampar.

Gambar 2. Water quality index (IKL) from five sampling stations in Kampar River.

Hasil analisis kelompok ditunjukkan oleh dendogram (Gambar 3), teridentifikasi tiga kelompok habitat perairan ikan belida di Sungai Kampar yang memiliki perbedaan karakteristik habitat yang mendasar yaitu; (1) kelompok habitat perairan tergenang pada Stasiun Kutopanjang, (2) habitat perairan mengalir tidak dipengaruhi pasang surut air laut yang berada di Sungai Kampar bagian hulu pada Stasiun Teso dan (3) Sungai Kampar bagian tengah-hilir, bagian perairan yang dipengaruhi pasang surut air laut yang meliputi Stasiun Langgam, Rantau Baru dan Kuala Tolam.

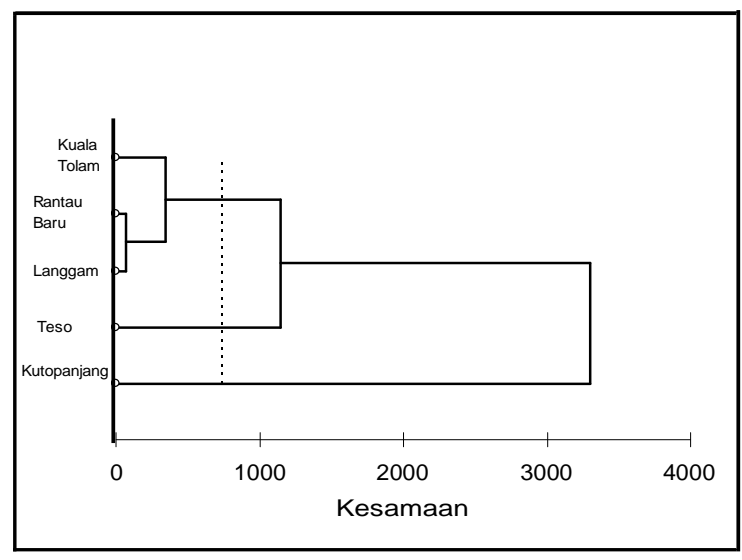

Gambar 3. Dendogram kesesuaian karakteristik perairan lima stasiun pengambilan sampel.

Figure 3. Similiarty dendogram of water quality from five sampling stations.

Scaterplot PCA (Gambar 4), dapat menjelaskan data hingga 77,68 \% dari data asli (masing-masing stasiun), berdasarkan nilai komponen utama (axe 1 dan axe 2) yang memberikan kontribusi sebesar 77,68 \% dari keragaman total. Stasiun Kutopanjang dan Langgam dicirikan terutama oleh level yang tinggi dari variabel kedalaman, pH dan suhu air. Karakteristik kondisi parameter kualitas air yang berlawanan (level yang rendah dari variabel kedalaman, pH, kecerahan dan suhu air) dimiliki oleh Rantau Baru, selain hal tersebut stasiun ini juga dicirikan oleh level yang tinggi dari turbidity, amoniak (NH3-H), faktor kondisi, kecepatan arus dan luas relung. Stasiun Kuala Tolam dicirikan oleh kandungan oksigen terlarut yang lebih rendah dan nilai yang tinggi dari parameter alkalinitas, TDS, tutupan vegetasi, nilai $\mathrm{K}$ (koefisien pertumbuhan) dan nilai b (slope regresi antara logaritma yang diperoleh dari hubungan panjang dan berat), kondisi sebaliknya ditemukan di Stasiun Teso (Gambar 4).

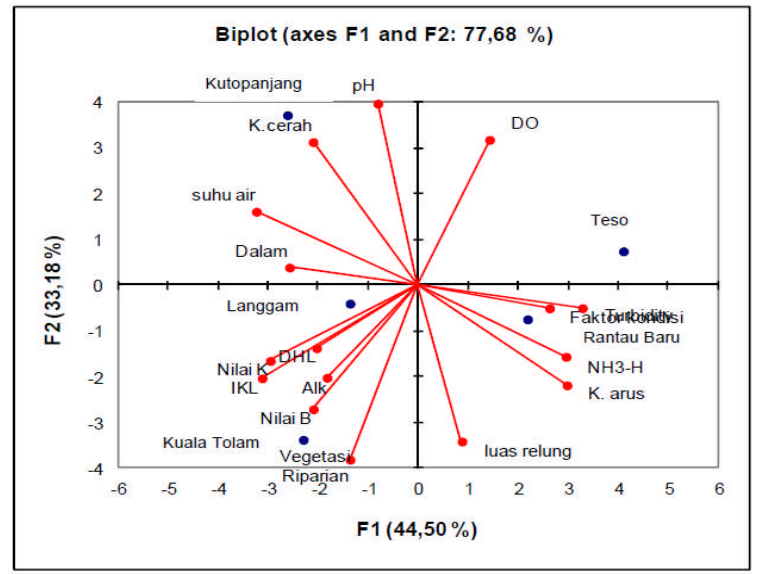

Gambar4. Hasil analisis komponen utama parameter lingkungan perairan, faktor kondisi ikan dan kualitas perairan.

Figure 4. Principle component analysis result of sampling stations, fish condition and water quality. 


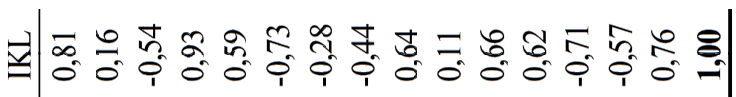

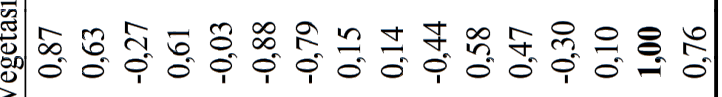

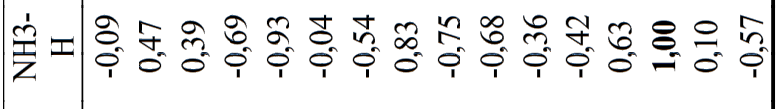

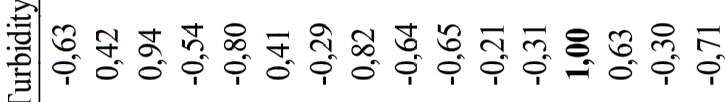

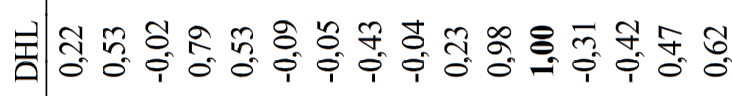

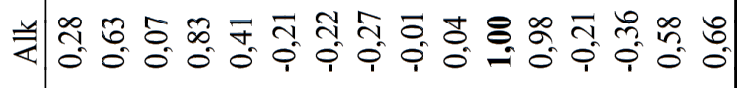

番

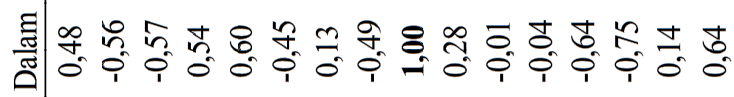

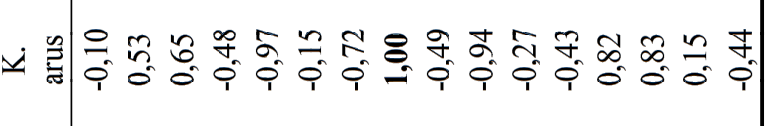

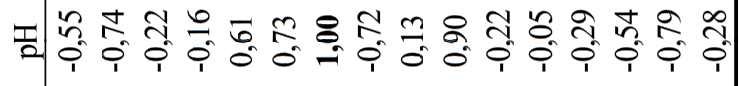

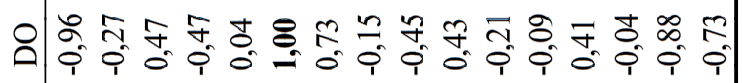

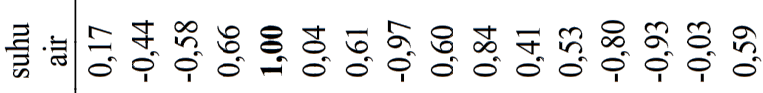

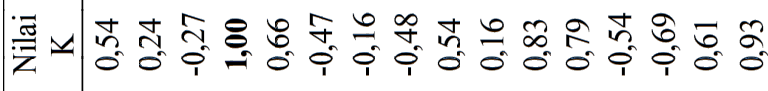

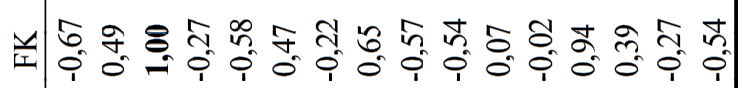

象

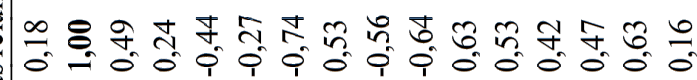

产

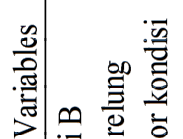

产

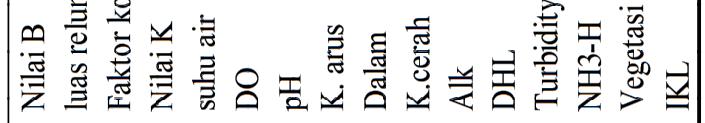


Dilihat dari parameter korelasi yang diperoleh dari perhitungan PCA dengan XLstat (Tabel 3), nilai indeks kualitas lingkungan (nilai ini berasal dari penilaian dengan pembobotan semua parameter perairan setiap stasiun) memiliki korelasi yang tinggi dengan nilai K (koefisien pertumbuhan). Penilaian indeks kualitas lingkungan perairan setiap stasiun pengamatan disajikan pada Lampiran 1. Hal ini menunjukkan bahwa kondisi habitat lingkungan perairan mempengaruhi biologi pertumbuhan ikan yang ada pada setiap stasiun pengamatan. Indeks kualitas lingkungan memiliki keterkaitan dengan pertumbuhan ikan belida (nilai b dan nilai K), dengan keterkaitan yang paling kuat dengan nilai $\mathrm{K}$.

Berdasarkan penilaian kondisi habitat yang paling baik, Stasiun Kuala Tolam di Sungai Kampar Prov. Riau merupakan kandidat yang tepat untuk direkomendasikan sebagai wilayah konservasi ikan belida.

\section{BAHASAN}

Adanya perbedaan besaran nilai dan variasi kondisi kualitas perairan pada setiap waktu pengamatan di stasiun penelitian sepanjang Sungai Kampar selama penelitian, terkait dengan karakteristik stasiun penelitian, perubahan musim dan besaran curah hujan.

Stasiun Kuala Tolam memiliki nilai indeks kualitas lingkungan yang paling baik, stasiun ini dicirikan oleh kandungan oksigen terlarut yang rendah dan nilai yang tinggi dari parameter alkalinitas, TDS, tutupan vegetasi, $\mathrm{K}$ (koefisien pertumbuhan), dan nilai b (slope regresi antara logaritma yang diperoleh dari hubungan panjang dan berat). Walaupun kandungan oksigennya rendah $(4.57 \mathrm{mg} /$ 1, lampiran 1) namun dikategorikan baik, Menurut Effendi (2003), nilai oksigen perairan yang baik untuk organisme air sebaiknya lebih dari $4 \mathrm{mg} / \mathrm{l}$, oksigen terlarut kurang dari $2 \mathrm{mg} / \mathrm{l}$ dapat menyebabkan kematian beberapa jenis ikan. Nilai oksigen yang rendah dan TDS yang tinggi dimungkinkan terkait dengan keberadaan vegetasi riparian yang rapat yang menyumbang bahan organik ke sungai. Level yang tinggi dari masukan bahan organik ke sungai memacu aktivitas mikroorganisme (bakteri) yang kemudian menggunakan oksigen yang tersedia sehingga menurunkan kadar oksigen terlarut. Konsentasi bahan organik yang tinggi dari vegetasi riparian (TDS) berasosiasi dengan meningkatnya tingkat alkalinitas perairan. Alkalinitas adalah gambaran kapasitas air untuk menetralkan asam atau dikenal dengan sebutan acid neutralizing capacity (ANC) atau kuantitas anion di dalam air yang dapat menetralkan kation hidrogen. Alkalinitas berperan sebagai buffer perairan terhadap perubahan $\mathrm{pH}$ yang drastis, alkalinitas yang baik berkisar antara 40-500 $\mathrm{mg} / \mathrm{LCaCO}_{3}$ (Effendi, 1997).

Keberadaan vegetasi riparian menjadi salah satu kunci kualitas habitat ikan belida, merujuk pada sejarah hidup ikan belida. Induk ikan belida menempelkan telurnya pada benda-benda yang berada 1.5-2 m, di bawah permukaan air, termasuk pada batang kayu baik yang masih hidup maupun yang sudah mati (Adjie \& Utomo 1994). Batang kayu merupakan rumpon bagi ikan kecil dan udang yang merupakan makanan utama ikan ini, sehingga pada waktu melakukan pemijahan mudah mendapatkan makanan.

Indeks kualitas lingkungan memiliki keterkaitan dengan pertumbuhan ikan belida (nilai b dan nilai K), artinya semakin baik indeks kualitas lingkungan maka nilai b (slope regresi antara logaritma yang diperoleh dari hubungan panjang dan berat) dan nilai K (koefisien pertumbuhan) semakin tinggi. Sedangkan luas relung memiliki keterkaitan negatif dengan indeks kualitas air, hal ini diduga terkait dengan variasi makanan. Kondisi lingkungan yang semakin baik memberikan stimulan keberadaan makanan yang semakin bervariasi bagi ikan belida dan sebaliknya. Faktor kondisi yang memperlihatkan tingkat kegemukan ikan belida berbanding terbalik dengan indeks kualitas lingkungan, dapat dijelaskan bahwa ikan belida termasuk ke dalam kelompok ikan rawa (black water) (Welcomme, 1979; Welcomme, 2001) sehingga indeks lingkungan terbaik untuk ikan belida berada di tipe perairan asam. Tipe perairan ini bersifat asam dengan ketersediaan makanan di perairan yang terbatas yang diduga berkontribusi dalam bentuk ikan belida yang lebih kurus.

Pertumbuhan ikan dipengaruhi oleh faktor internal dan faktor eksternal. Faktor eksternal yang mempengaruhi pertumbuhan ikan yaitu jumlah dan ukuran makanan yang tersedia, jumlah ikan yang menggunakan sumber makanan dan faktor lingkungan (suhu, oksigen terlarut, kadar amonia di perairan dan salinitas) (Moyle \& Cech, 2006).

Terkait dengan hasil pengamatan ini, Stasiun Kuala Tolam dapat dijadikan kandidat yang tepat untuk wilayah konservasi ikan belida. Menurut King (1995), penetapan wilayah konservasi merupakan bagian yang tidak terpisahkan dari pengelolaan perikanan. Rekomendasi kebijakan perbaikan habitat disarankan pada stasiun Teso dan Rantau Baru. Pertimbangan ini didasarkan pada penilaian tingkat kondisi habitat yang paling rendah (buruk) diantara lima stasiun pengambilan sampel di Sungai Kampar Prov. Riau. Terlihat jelas kadar amoniak yang tinggi, tingginya besaran amoniak di kedua stasiun ini, diduga terkait dengan banyaknya aktivitas pemeliharaan ikan dalam keramba jaring apung (KJA) pada stasiun Rantau Baru dan keberadaan pabrik minyak kelapa sawit di sekitar stasiun Teso.

\section{KESIMPULAN}

Stasiun Kuala Tolam memiliki nilai indeks kualitas lingkungan perairan yang terbaik sedangkan Stasiun Teso dan Rantau Baru yang paling buruk. Nilai K memiliki keterkaitan yang paling kuat dengan indeks kualitas lingkungan. 


\section{DAFTAR PUSTAKA}

Abercrombie, M., C.J. Hickman, \& M.L. Johnson. 1966. A Dictionary of Biology. London: Penguin Reference Books. 246 p.

Adjie, S. \& A.D. Utomo. 1994. Aspek biologi ikan belida di perairan sekitar lubuk lampam Sumatera Selatan. Prosiding Seminar Penyusunan, Pengolahan dan Evaluasi Hasil Penelitian Perikanan Perairan Umum. Loka Perikanan Air Tawar. 32-36.

Adjie, S., Husnah \& A. K. Gaffar. 1999. Studi biologi ikan belida (Notopterus chitala) di daerah aliran Sungai Batanghari Provinsi Jambi. J. Penel. Perik. Indonesia. 1:38-43.

Affandi, R. 2011. Penilaian kualitas air dengan pembobotan. Komunikasi Pribadi.

APHA, AWWA \& WPCF. 1981. Standard Method for Examination of Water and Waste Water. Fifteenth Edition. Byrd Pre press and R.R. Donnelly Sons, USA. $1134 \mathrm{p}$.

Bain, M.B. \& N.J. Stevenson. 1999. Aquatic Habitat Assesment Common Methods. American Fisheries Society. Maryland. USA. 216 p.

Bengen, D.G. 2000. Sinopsis teknik pengambilan contoh dan analisis data biofisik sumberdaya pesisir. Pusat Kajian Sumberdaya Pesisir dan Lautan. Fakultas Perikanan dan Ilmu Kelautan IPB Bogor. $88 \mathrm{hlm}$.

Effendi, M.I. 1997. Biologi Perikanan. Yayasan Pustaka Nusatama. Yogyakarta. 62 hal.

Effendi, H. 2003. Telaah Kualitas Air Bagi Pengelolaan Sumberdaya dan Lingkungan Perairan. Kanisius. Yogyakarta. $258 \mathrm{p}$.

Goldsmith, F. B. 1983. Evaluating nature. in A. Warren \& F.B. Goldsmith. Pages 233-246 (eds.), Conservation in perspective. Wiley, Chichester, UK.

Jikalahari. 2009. www.jikalahari.org. Kampar Peninsula as a peat swamp forest conservation priority.
King, M. 1995. Fisheries Biology. Assesment and Management. Fishing News Books, Blackwell Science Ltd.

Kirkpatrick, J.B. 1983. An lterative method for establishing priorities for the selection of nature reserves: an example from Tasmania. Biological Conservation. 25: 127-134.

Legendre, P \& P. Legendre. 1998. Numerical Ecology. Second edition. Elsevier science, Amsterdam. 1015 p.

Moyle, P.B \& J.J. Cech. 1996. Fishes an Introduction to Ichthyology. Prentice Hall, New Jersey. 612 p.

Margules, C.R \& M.B. Usher. 1981. Criteria used in assessing wildlife conservation potential: a review. Biological Conservation. 21. 79-109.

Ramakrishnalah, C.R., C. Sadashivalah \& G. Ranganna. 2009. Assessment of water quality index for the groundwater in Tumkur Taluk, Karnataka State, India. Journal of Chemistry. 6 (2). 523-530.

Rosenberg, A., T. E. Bigford, S. Leathery, R. L. Hill, \& K. Bickers. 2000. Ecosystem approaches to fishery management through essential fish habitat. Bulletin of marine science. 66 (3). 535-542.

Rossi, E \& M. Kuitenen. 1996. Ranking of habitats for the assessment of ecological impact in land use planning. Biological Conservation. 77. 227-234.

Welcomme, R.L. 1979. Fisheries Ecology of Floodplain River. Longman. London. 317 p.

Welcomme, R.L. 2001. Inland Fisheries: Ecology and Management. Blackwell Science Ltd. London. xvii+353 p.

Wibowo, A. M.T.D. Sunarno \& S. Makmur. 2009. Parameter fisika, kimia, dan biologi penciri habitat ikan belida (Chitala lopis). Jurnal Penelitian Perikanan Indonesia. 15 (1). 13-21.

Wibowo, A. 2011. Bioekologi Ikan Belida (Chitala lopis) di Sungai Kampar, Provinsi Riau. Disertasi. Program Pasca sarjana, Institut Pertanian Bogor. 


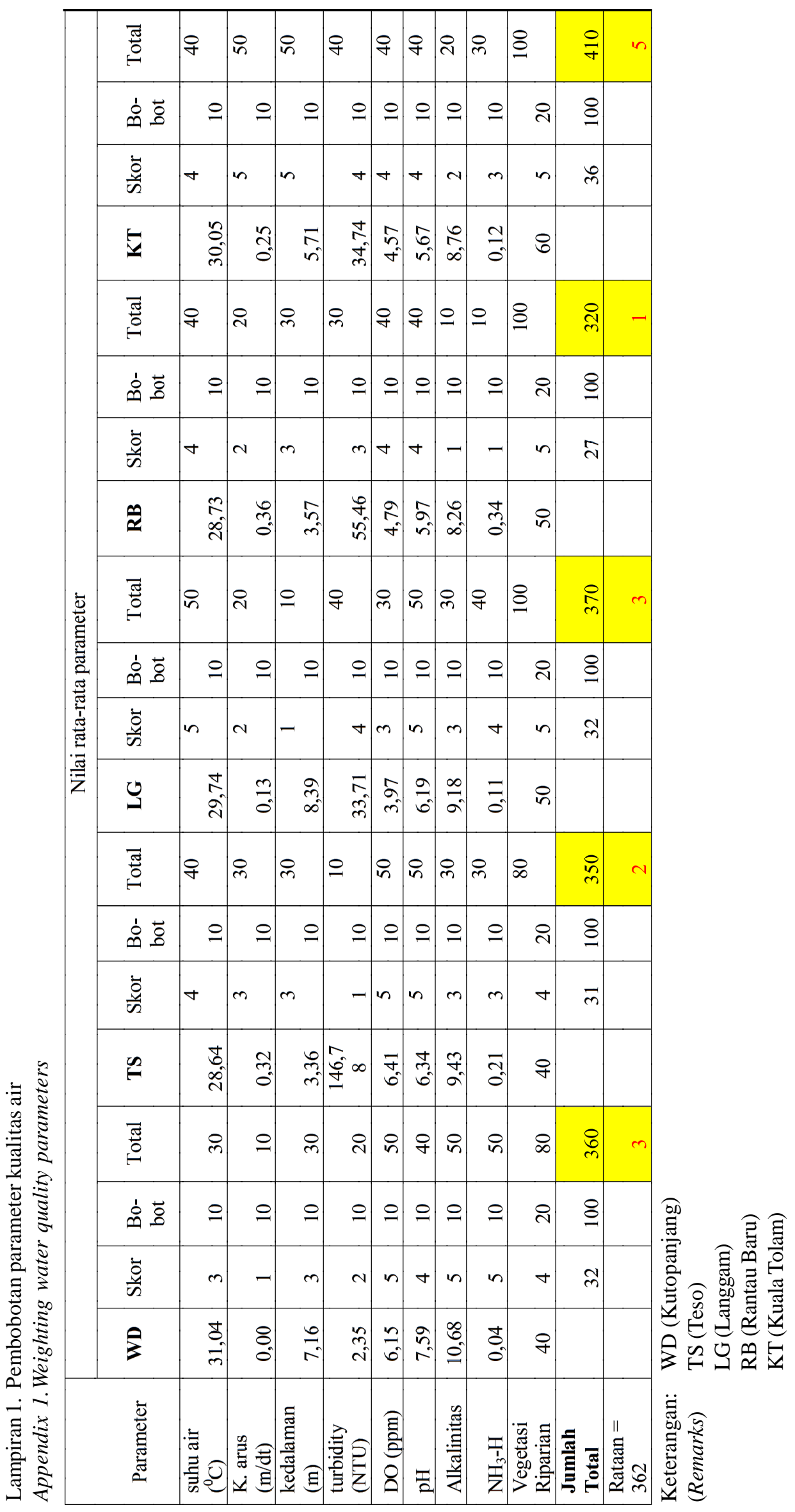

